\title{
ŹRÓDLA DO DZIEJÓW ZGROMADZENIA CÓREK BOŻEJ MILOŚCI W GENERALNYM ARCHIWUM ZGROMADZENIA CÓREK BOŻEJ MIŁOŚCI W WIEDNIU
}

W przestawieniu podstaw źródłowych do dziejów Zgromadzenia Córek Bożej Miłości, koniecznym jest ukazanie w krótkim zarysie jego charakteru, organizacji i działalności.

Zgromadzenie Córek Bożej Miłości założyła 21 listopada 1868 roku w Wiedniu Franciszka Lechner. Jego głównym celem była początkowo opieka nad dziewczętami, które masowo migrowały ze wsi do miast w poszukiwaniu pracy. W latach późniejszych siostry Córki Bożej Miłości poświęciły się działalności oświatowo-wychowawczej, zakładając na terenie byłej monarchii austro-węgierskiej tzw. Instytuty Marii, w których funkcjonowały schroniska dla służących, szkoły różnego typu, ochronki oraz internaty. Rozwój organizacyjno-prawny Zgromadzenia przebiegał w kilku etapach. Pierwszy z nich to uznanie go w 1879 roku za zgromadzenie zakonne przez władze kościelne na poziomie diecezji, a w 1882 roku również przez władze cywilne. Następnie w latach 1884-1897 Zgromadzenie uzyskało potrójne zatwierdzenie na prawie papieskim. Do I wojny światowej rozwijało się ono na terenie byłej monarchii austro-węgierskiej. W 1913 roku rozpoczęło działalność w Stanach Zjednoczonych, a w 1914 roku w Anglii. Od 1920 roku Córki Bożej Miłości obecne są w Brazylii. Dnia 1 lipca 1919 roku doszło do pierwszego podziału Zgromadzenia na prowincje: jugosłowiańską, węgierską, polską i czeską. Placówki w Austrii, Anglii, Stanach Zjednoczonych i Brazylii znalazły się wówczas pod zarządem generalnym, rezydującym w Domu Macierzystym w Wiedniu. Prowincja amerykańska powstała dopiero w 1921 roku, a w 1950 i 1972 roku rozpadła się dalsze dwie prowincje. W 1938 roku utworzone zostały dwie prowincje brazylijskie: południowa i północna. Prowincja słowacka wyodrębniła się w 1927 roku. W 1966 roku

„Nasza Przeszłość” t. 131: 2019, s. 241-256. 
Zarząd Generalny Zgromadzenia, mający podówczas swą siedzibę w Wiedniu, przeniósł się do Grottaferrata w Rzymie. Tym samym erygowana została prowincja austriacka, która obejmowała placówki w Austrii i Niemczech.

Podsumowując, przełomowym momentem w dziejach Zgromadzenia Córek Bożej Miłości był jego podział na prowincje. Do 1919 roku Zgromadzenie posiadało 84 domy na terenie Europy Środkowej, Anglii i Stanów Zjednoczonych. Najwięcej placówek, bo aż 75 powstało w byłych Austro-Węgrzech. Tylko trzy z nich mieściły w Galicji. Były to: klasztor św. Hildegardy w Białej Krakowskiej, Instytut Marii w Krakowie oraz klasztor Villa Providentiae na Woli Justowskiej, będący początkowo filią domu krakowskiego. Od utworzenia w 1919 roku Polskiej Prowincji Zgromadzenia Córek Bożej Miłości do wybuchu II wojny światowej powstawały kolejne domy w Pabianicach, Wilkowicach, Pleszowie pod Krakowem i w Jastrzębiu Dolnym. We wszystkich tych placówkach prowadzono działalność oświatowo-wychowawczą oraz pomagano najuboższym. Siostry z Polskiej Prowincji prowadziły różne typy szkół i instytucji wychowawczych: przytuliska dla służących, szkoły ludowe i wydziałowe, internaty, przedszkola, szkoły robót, seminaria nauczycielskie, gimnazja, licea oraz różne kursy: gotowanie, szycie, lekcje muzyki i języki obce. Dominującą formą działalności Zgromadzenia na ziemiach polskich były szkoły, których największy rozkwit przypadł na lata międzywojenne. W okresie okupacji hitlerowskiej działalność ta została prawie całkowicie przerwana. Po II wojnie światowej misja Zgromadzenia w Polsce uległa zasadniczym przeobrażeniom. Na skutek likwidacji przez państwo zakładów szkolnowychowawczych w latach 1947-1950, siostry pracowały głównie jako zakrystianki, kancelistki i katechetki przy parafiach, zajmowały się pracą chałupniczą oraz prywatną opieką nad dziećmi. Do działalności szkolnej powróciły dopiero po 62 latach, reaktywując w 2001 roku w Bielsku-Białej gimnazjum z czterema oddziałami klas pierwszych, a w następnym roku liceum ogólnokształcące.

Obecnie misja Zgromadzenia Córek Bożej Miłości kontynuowana jest w osiemnastu krajach przez siostry z siedmiu prowincji i trzech wice prowincji. Członkinie Polskiej Prowincji pracują w 25 domach w kraju i za granicą. W większości z nich mieszczą się placówki dla dzieci i młodzieży: przedszkola, szkoły, bursy dla studentek, domy pomocy społecznej, zakład opiekuńczo-leczniczy, ośrodek rewalida- 
cyjno-wychowawczy, ośrodek socjoterapeutyczny oraz dom samotnej matki. Apostolstwo Zgromadzenia obejmuje również katechizację oraz pomoc najuboższym.

Podejmowana przez Zgromadzenie Córek Bożej Miłości działalność w zasadniczy sposób wpłynęła na charakter wytworzonej dokumentacji. Opracowując historię Zgromadzenia, przeprowadziłam w pierwszej kolejności kwerendę w Generalnym Archiwum Zgromadzenia Córek Bożej Miłości, mieszczącym się w Wiedniu przy Jacquingasse 12-14. Uporządkowaniem zasobu tego archiwum zajmowała się w latach 1885-1991 siostra Zofia Rusztyn. Jej praca zakończyła się wydaniem książkowego inwentarza archiwalnego ${ }^{1}$, który zawiera dokładny wykaz akt całego Zgromadzenia wraz z krótkim opisem wszystkich jednostek archiwalnych wchodzących w skład poszczególnych grup rzeczowych.

Jak wspomniała we wstępie autorka inwentarza, na rozmiar i rodzaj dokumentacji archiwalnej znajdującej się obecnie w archiwum generalnym, wpłynęła struktura Zgromadzenia. Do 1919 roku, czyli do momentu wyodrębnienia pierwszych czterech prowincji, zarządzane ono było centralnie. Oznacza to, że wszystkie sprawy kierowane były do zarządu generalnego rezydującego $\mathrm{w}$ Wiedniu. W konsekwencji podziału na prowincje, zorganizowano w nich samodzielne sekretariaty. Odtąd większość dokumentacji pozostawała w prowincjach. Do Generalatu trafiały jedynie akta bardziej ogólne i selektywne ${ }^{2}$. Spuściznę aktową generalnego zasobu archiwalnego stanowią własne archiwalia Zgromadzenia od $1868^{3}$ do 1991 roku. Znaczna część zasobu tego archiwum dotyczy prowincji austriackiej, co spowodowane jest lokalizacją archiwum na terenie tej prowincji. W sumie zasób archiwum generalnego obejmuje 795 jednostek archiwalnych i wynosi około 8,3 metrów bieżących ${ }^{4}$. Materiał archiwalny został podzielony na dwie części: akta całego Zgromadzenia i akta poszczególnych prowincji. W aktach dotyczących całego Zgromadzenia wyodrębnione zostały następujące grupy i podgrupy rzeczowe:

\footnotetext{
${ }^{1}$ Z. R u s z t y n, Inwentarz generalnego zasobu archiwalnego Zgromadzenia Córek Bożej Miłości w Wiedniu (1848-1991), ABMK, t. LXVI, Lublin 1996, s. 11-206.

2 Tamże, s. 12.

${ }^{3}$ Pojedyncze akta pochodzą od 1848 roku.

${ }^{4} \mathrm{Z}$. R u s z t y n, Inwentarz generalnego zasobu archiwalnego..., s. 13.
} 
1. Akta ustawodawcze: Statuty, Konstytucje, Reguły, dokumentacja związana z aprobatą Zgromadzenia i Konstytucji, Rytuały, modlitewniki, odpusty $i$ inne.

2. Akta zarządu Zgromadzenia: materiały Kapituł Generalnych, uchwały i zarządzenia przełożonych generalnych, okólniki i sprawozdania Założycielki, kolejnych przełożonych generalnych oraz Rady Generalnej, akta posiedzeń Rady Generalnej, nominacje przełożonych, akta nowicjatu, dokumentacja dotycząca podziału zgromadzenia na prowincje oraz związana $\mathrm{z}$ otwieraniem nowych domów.

3. Sprawozdawczość: zestawienia roczne, sprawozdania z działalności, sprawozdania i przeglądy statystyczne, schematyzmy, statystyka wewnętrzna.

4. Władze kościelne. Dokumenty oraz korespondencja z Ojcem Świętym, Stolicą Apostolską, kardynałami protektorami, duchowieństwem wyższym, Nuncjaturą Apostolską w Wiedniu, Ordynariatami oraz osobami prywatnymi.

5. Korespondencja z władzami kościelnymi i cywilnymi, dzienniki podawcze,

6. Dokumentacja ewidencyjna dotycząca członkiń Zgromadzenia: księgi ewidencyjne sióstr, księgi obłóczyn, księgi profesji wieczystej, spisy uczestniczek rekolekcji.

7. Włączenie do Zgromadzenia Córek Bożej Miłości: kandydatki, nowicjuszki, obłóczyny, profesja.

8. Siostry zmarłe: akta personalne, wspomnienia pośmiertne, nekrologi, rożne spisy zmarłych sióstr.

9. Członkinie, które opuściły Zgromadzenie.

10. Formacja duchowa. Duchowość.

11. Spuścizna członkiń Zgromadzenia Córek Bożej Miłości: Założycielki Matki Franciszki Lechner, Matki Ignacji Egger, Matki Kostki Bauer, Matki Huberty Buchanan, siostry Teresiny Werner $\mathrm{i}$ innych sióstr.

12. Opracowania pisemne i inne dzieła: historia Zgromadzenia i poszczególnych prowincji, jubileusze Zgromadzenia, utwory literackie, sceniczne, poezja, życzenia. 
13. Kroniki, księgi pamiątkowe: kroniki całego Zgromadzenia, kroniki domów prowincji austriackiej, księgi pamiątkowe.

14. Zdjęcia.

15. Filmy, kasety, taśmy magnetofonowe.

16. Spuścizna sfragistyczna: pieczątki, medale.

17. Dokumentacja techniczna.

18. Druki, maszynopisy: książki, czasopisma.

Drugą część zasobu archiwum generalnego stanowią archiwalia poszczególnych prowincji. Jest to przeważnie dokumentacja domów, związana z ich zakładaniem i likwidowaniem (umowy kupna, nowe budowy, plany budowlane itp.) oraz korespondencja $\mathrm{z}$ władzami Zgromadzenia, urzędami świeckimi i kościelnymi, różne sprawozdania, statystyka. Ze zrozumiałych powodów ta część zasobu w większym wymiarze obejmuje materiał archiwalny prowincji austriackiej. Rozpracowany plan akt i spis treści Inwentarza, dokładnie ukazują zawartość i strukturę całego zasobu Archiwum Generalnego Zgromadzenia Córek Bożej Miłości ${ }^{5}$.

Podstawowymi źródłami do opisania dziejów sióstr Córek Bożej Miłości są kroniki generalne ${ }^{6}$, zawierające informacje od chwili założenia Zgromadzenia do 1966 roku$^{7}$. Pisane one były w sposób narracyjny,

\footnotetext{
${ }^{5}$ Por. tamże, s. 17-23.

${ }^{6}$ Generalarchiv der Kongregation der Töchter der Göttlichen Liebe in Wien (dalej: GA-KTGL): sygn. EIIa 1, Chronik der Gesellschaft der Töchter der Göttlichen Liebe von derer Entstehen in Wien bis zum heutigen Tage am 31. Oktober 1876; sygn. EIIa 2, Chronik der Gesellschaft der Töchter der Göttlichen Liebe von derer Entstehen in Wien am 21 November 1868 bis zum heutigen Tage 1. November 1876; sygn. EIIa 3, Chronik der Gesellschaft der Töchter der Göttlichen Liebe vom 1. November 1876 bis 1. Mai 1885; sygn. EIIa 4, Chronik der Gesellschaft der Töchter der Göttlichen Liebe vom 1. Mai 1885 bis 25. April 1893; sygn. EIIa 5, Chronik der Kongregation der Töchter der Göttlichen Liebe vom Mai 1893 bis Oktober 1898; sygn. EIIa 6, Chronik der Gesellschaft der Töchter der Göttlichen Liebe vom Oktober 1898 bis Ende Juni 1909; sygn. EIIa 7, Chronik der Kongregation der Töchter der göttlichen Liebe 1909-1921; EIIa 8, Chronik der Kongregation der Töchter der göttlichen Liebe 1921-1939; EIIa 9, Chronik der Kongregation der Töchter der göttlichen Liebe 1940-1966.

${ }^{7}$ W zasobie Archiwum Generalnego Zgromadzenia Córek Bożej Miłości w Wiedniu są tylko kroniki generalne prowadzone do 1966. Kroniki od 1966 roku są w archiwum Generalatu w Rzymie.
} 
pismem gotyckim odręcznym. Wiele z nich posiada niemieckie odpisy w maszynopisie, które sporządziły dwie siostry z prowincji austriackiej: siostra Anysia Nitsche i siostra Imelda Andre. Jedna z kronik stanowi wydanie okolicznościowe z okazji 25 . rocznicy założenia Zgromadzenia ${ }^{8}$. W okresie 1869-1893 kroniki były pisane pod dyktando samej założycielki Franciszki Lechner lub przez nią sprawdzane. W 1884 roku ponownie przepisano pierwszą kronikę oraz ją uzupełniono. Analiza tekstu kronik pozwala wysunąć przypuszczenie, że przepisywano je z konceptów ${ }^{9}$. Kroniki są przede wszystkim cennym źródłem wiadomości o początkach Zgromadzenia. Podają okoliczności jego powstania oraz ukazują jego dynamiczny rozwój pod względem liczebnym i organizacyjnym. Przedstawiają również historię powstawania kolejnych placówek oraz działalność sióstr. Zapisy kronikarskie przynoszą też relacje z życia codziennego wspólnot. Ukazują problemy, z którymi musiało się zmagać młode Zgromadzenie oraz jego zwyczaje i tradycje. Obok notatek z życia sióstr, kronikarka zamieszczała w nich także krótkie informacje o ważnych wydarzeniach w świecie.

Inną ważną grupę archiwaliów do badania historii Zgromadzenia stanowią akta normatywne: Statuty $^{10}$, Reguły ${ }^{11}$, Konstytucje ${ }^{12}$ oraz

${ }^{8}$ GA-KTGL, sygn. EIIa 10, Chronik der Congregation der Töchter der Göttlichen Liebe verfasst aus Anlass des 25jährigen Bestandes der Gesellschaft, Wien 1893.

${ }^{9}$ K. Z. R u s z t y n, Zgromadzenie Córek Bożej Miłości w latach 1868-1919. Struktura i rozwój terytorialny, Lublin 2004, s. 14.

${ }^{10}$ GA-KTGL: sygn. AIa 1, Allgemeine Statuten der Gesellschaft von der Göttlichen Liebe. Von der k. k. niederösterreichischen Statthalterei genehmigt Laut hohen Erlaß ddo. 30 April 1869, Z. 11655; sygn. AIa 2, Grundzüge der wohlthätigen Gesellschaft von der Göttlichen Liebe, [1869]; sygn. AIa 3, Allgemeine Statuten der Gesellschaft von der Göttlichen Liebe (Bescheinigung des Bestandes des Vereines von der k.k. Statthalterei, Z. 33242, Wien, den 12. November 1870); sygn. AIa 4, Allgemeine Statuten der Gesellschaft der Töchter der Göttlichen Liebe, genehmigt von dem k.k. Ministerium des Innern und der k. k. Statthalterei mittelst hohem Erlass ddo. [12] November 1870, Z. 33242; sygn. AIa 5, Statuta generalia Societatis Filiarum Caritatis Divinae, 12 Novembri 1870, n. 33242; sygn. AIa 6, Allgemeine Statuten. Änderungen, 1875, 1894, 1922; sygn. AIa 7, Schriftstücke bezüglich der staatlichen Bescheinigung des Bestandes der Gesellschaft von der Göttlichen Liebe und der Gesellschaft der Töchter der Göttlichen Liebe mit den Änderungen der allgemeinen Statuten, 1869-1938; sygn. AIa 8, Dekret und Statuten der Schwestern für die Krankenpflege, 1914-1948; sygn. AIa 9, Statuten der Gesellschaft der Töchter der Göttlichen Liebe, gestiftet im Jahre des Heiles 1868. Alles Dir zu lieb o Gott!, 1871.

${ }^{11}$ GA-KTGL: sygn. AIb 1, Satzungen und Regeln der Gesellschaft der Töchter der göttlichen Liebe nach der Regel des hl. Augustinus, Wien 1879; sygn. AIb 17, Regel 
dokumentacja związana $\mathrm{z}$ ich opracowywaniem i zatwierdzaniem ${ }^{13}$. Analiza tych dokumentów pozwala między innymi prześledzić, jak zmieniała się struktura organizacyjno-prawna Zgromadzenia, które w chwili powstania było dobroczynnym związkiem religijnym. Dopiero po spełnieniu określonych wymogów prawa kościelnego i państwowego, uzyskało stosowne zatwierdzenia i status zgromadzenia zakonnego. $\mathrm{Z}$ dokumentów tych wiadomo również, że wraz z przemianami organizacyjno-prawnymi, modyfikacji ulegała nazwa Zgromadzenia: „Dobroczynne Stowarzyszenie Bożej Miłości”, „Stowarzyszenie Bożej Miłości”, „Stowarzyszenie Córek Bożej Miłości”, „Zgromadzenie Córek Bożej Miłości" ". Kolejne wydania Statutów są cennym źródłem do badań nad przemianami zachodzącymi w wewnętrznej strukturze Zgromadzenia oraz nad sposobem jego działania i zadaniami. Dostarczają one ważnych informacji na takie tematy, jak: cel, środki i tworzenie stowarzyszenia, siedziba, prawa i obowiązki członków, organy zarządzania, podejmowanie ważnych decyzji, sposób załatwiania spraw spornych, reprezentowanie stowarzyszenia na zewnątrz. Statuty ukazują również

des hl. Augustinus. Die Ordensregel. Sinn und Geist der Regel mit Einführung und Erklärung, Würzburg 1962.

${ }^{12}$ GA-KTGL: AIb 3, Anmerkungen zu den Konstitutionen, [1883-1883]; sygn. AIb 4, Constitutiones Societatis Filiarum Divinae Charitatis, 1891; sygn. AIb 5, Constitutiones Societatis Filiarum Divinae Charitatis (Text von 1891 mit Änderungen u. Dekret von 1897); sygn. AIb 6, Constitutiones Societatis Filiarum Divinae Charitatis, 1897; sygn. AIb 7, Konstitutionen der Gesellschaft der Töchter der göttlichen Liebe, Wien 1899; sygn. AIb 8, Constitutiones Societatis Filiarum Divinae Charitatis, 1921-1924; sygn. AIb 9, Constitutiones Societatis Filiarum Divinae Charitatis, 1924; sygn. AIb 10, Bemerkungen und Änderungen der Konstitutionen, 1884-1924; sygn. AIb 11, Verschiedene Entwürfe der Konstitutionen, ...-1897-1920; sygn. AIb 12, Konstitutionen der Gesellschaft der Töchter der göttlichen Liebe, Wien 1927; sygn. AIb 14, Konstitutionen der Gesellschaft der Töchter der Göttlichen Liebe, 1968; sygn. AIb 15, Lebensform der Kongregation der Töchter der Göttlichen Liebe, Grasl, BadVöslau 1979; sygn. AIb 18, Anhang zu den Konstitutionen der Gesellschaft der Töchter der Göttlichen Liebe, [1983]; sygn. AIb 19, Constitutions and General Directory of the Congregation of the Daughters of Divine Love, 1984; sygn. AIb 20, Konstitutionen der Gesellschaft der Töchter der Göttlichen Liebe mit der Regel des heiligen Augustinus, 1990; sygn. Alb 21; Generaldirektorium der Kongregation der Töchter der Göttlichen Liebe, 1990.

${ }^{13}$ GA-KTGL: sygn. AIc 1, Decretum laudis (Belobungsdekret), 1884; sygn. AIc 2, II. Approbation der Kongregation und der Konstitutionen, 1891; sygn. AIc 3, III. Bestätigung der Konstitutionen, 1896; sygn. AIc 4, III. Endgültige Approbation der Konstitutionen, 1896-1897.

${ }^{14}$ GA-KTGL, por. sygn. AIa 1, AIa 2, AIa 3, DIg 7 - strony tytułowe. 
religijny wymiar wspólnoty, określają jej charyzmat i duchowość. Oprócz wielu wskazówek teologicznych i ascetycznych, zawierają bowiem informacje o ślubach zakonnych, porządku domowym, nabożeństwach i ćwiczeniach duchownych sióstr oraz praktykach religijnych podopiecznych. W Konstytucjach szczególnie interesujące są rozdziały traktujące o prawach i obowiązkach sióstr. Bardzo szczegółowo opisane w nich zostały reguły dla sióstr pracujących na różnych stanowiskach: przełożonych generalnych i prowincjalnych, asystentek, admonitorek, sekretarek, prokuratorek, przełożonych domowych, mistrzyń formacji, dozorczyń, nauczycielek, bibliotekarek, zakrystianek, furtianek, mistrzyń kuchni, pielęgniarek, kwestarek i innych.

Kwerenda w Archiwum Generalnym w Wiedniu wykazała, że bardzo mało jest w nim materiału dotyczącego członkiń Zgromadzenia. Księga ewidencyjna z lat 1869-1958 zawiera alfabetyczny spis sióstr ${ }^{15}$. Podano w niej tylko imiona i nazwiska zakonne oraz odsyłacze do tzw. kronik sióstr, które dziś już nie istnieją, a które zawierały prawdopodobnie wszystkie dane personalne członkiń Zgromadzenia. Przypuszcza się, że księgi te, w liczbie około 150, mogły zaginąć podczas dwukrotnego przenoszenia siedziby zarządu generalnego w 1888 i 1965 roku ${ }^{16}$. Podstawowych danych personalnych, takich jak data, miejsce urodzenia i wykształcenie nie podaje też spis kandydatek obłóczonych w latach 1869-1968 ${ }^{17}$. Dokładniejsze pod tym względem są księgi ewidencyjne kandydatek obłóczonych po 1914 roku $^{18}$, w których oprócz daty i miejsca urodzenia, podano również miejsce chrztu i bierzmowania, datę i miejsce wstąpienia do Zgromadzenia, zawód ojca, rodzaj wykonywanej pracy w Zgromadzeniu oraz datę pierwszej profesji. Niestety księgi ewidencyjne wieczystej profesji zawierają już tylko imiona i nazwiska sióstr, które w latach 1884-1968 złożyły śluby wieczyste ${ }^{19}$. Przy nazwi-

\footnotetext{
${ }^{15}$ GA-KTGL, sygn. BIa 1, Verzeichnis der Schwestern, 1869-1958.

${ }^{16}$ K. Z. R u s z t y n, Zgromadzenie Córek Bożej Miłości w latach 1868-1919..., s. 11-12.

17 GA-KTGL, BIb 1, Einkleidung - gesamte Kongregation. A - Z. Alphabetischchronologisches Verzeichnis, [1869-1968].

18 GA-KTGL, sygn. BIb 2, Einkleidung - gesamte Kongregation, chronologisches Verzeichnis, 1914-1929; GA-KTGL, sygn. BIb 3, Einkleidung - gesamte Kongregation, chronologisches Verzeichnis nach den Provinzen, 1929-1963; GA-KTGL, sygn. BIb 8, Einkleidung. Polnische Provinz, chronologisches Verzeichnis, 1964-1973.

19 GA-KTGL, sygn. BIc 1, Ewige Profeß. Gesamte Kongregation, chronologisches Verzeichnis, seit 1921 - nach den Provinzen geordnet, 1884-1940; GA-KTGL, sygn. BIc 2, Ewige Profeß. Gesamte Kongregation nach den Provinzen geordnet, 1940-1968.
} 
skach niektórych z nich dopisano później datę śmierci. Protokoły z posiedzeń Rady Prowincjalnej z dołączonymi do nich pisemnymi opiniami o kandydatkach, nowicjuszkach i siostrach, podają tylko krótką charakterystykę członkiń oraz decyzję rady o dopuszczeniu ich do obłóczyn lub ślubów ${ }^{20}$. W zasobie archiwum brakuje też dokumentacji przełożonych i asystentek. W sumie znajduje się w nim tylko jedna księga zawierająca imiona i nazwiska przełożonych oraz asystentek poszczególnych wspólnot, w której podano również okres sprawowania przez nie funkcji. Spis ten obejmuje lata od 1919 do $1946^{21}$. Braki w materiałach ewidencyjnych nastręczają dzisiaj sporych trudności w ustaleniu danych personalnych, terytorialnych czy pochodzenia społecznego członkiń Zgromadzenia. Pewną pomocą w uzupełnianiu tych informacji są akta personalne zmarłych sióstr ${ }^{22}$, wspomnienia pośmiertne i nekrologi ${ }^{23}$ oraz różne spisy zmarłych członkiń Zgromadzenia ${ }^{24}$.

Do opracowania tematyki związanej z działalnością Zgromadzenia mogą posłużyć sprawozdania statystyczne z lat 1895-1938. Ukazują one liczebność poszczególnych grup osób, do których skierowana była działalność zgromadzenia. Pierwsza księga sprawozdań zawiera

${ }^{20}$ GA-KTGL, sygn. BIIc 5, Urteile über die Kandidatinnen, die zur Einkleidung und über die Novizinnen und Schwestern, die zur Ablegung der Gelübde zugelassen werden - polnische Provinz, 1927-1941.

${ }^{21}$ GA-KTGL, sygn. BIa 2, Verzeichnis der Oberinnen und Assistentinnen, 1919-1946.

22 GA-KTGL: sygn. BIIIa 1, Personalakten der verstorbenen Schwestern. A-Berg., 1945-1986; sygn. BIIIa 2, Personalakten..., Bern-Brunn, 1938-1970; sygn. BIIIa 3, Personalakten..., C-D, 1944-1982; sygn. BIIIa 4, Personalakten..., E-F, 1936-1982; sygn. BIIIa 5, Personalakten..., G-Hal, 1946-1987; sygn. BIIIa 6, Personalakten..., Ham-Hyll, 1940-1988; sygn. BIIIa 7, Personalakten..., I-J, 1941-1989; sygn. BIIIa 8, Personalakten..., K-Korp, 1942-1987; sygn. BIIIa 9, Personalakten..., Kott-Krow, 1944-1971; sygn. BIIIa 10, Personalakten..., L-May, 1927-1988; sygn. BIIIa 11, Personalakten..., Mei-Mud, 1927-1973; sygn. BIIIa 12, Personalakten..., N-O-Pick, 1935-1984; sygn. BIIIa 13, Personalakten..., Pli-Puch, 1943-1990; sygn. BIIIa 14, Personalakten..., R, 1943-1988; sygn. BIIIa 15, Personalakten..., Saa-Scho, 19421980; sygn. BIIIa 16, Personalakten..., Schu-Stein, 1942-1990; sygn. BIIIa 17, Personalakten..., Stein-Strob, 1939-1989; sygn. BIIIa 18, Personalakten..., T-V, 1943-1985; sygn. BIIIa 19, Personalakten..., W, 1944-1982; sygn. BIIIa 20, Personalakten..., Z-Ž, 1937-1988.

${ }^{23}$ GA-KTGL: sygn. BIIIb 1, Nachrufe der Verstorbenen Schwestern, 1926-1969; sygn. BIIIb 2, Nachrufe..., 1926-1932; sygn. BIIIb 3, Nachrufe...,1977-1984; sygn. BIIIb 4, Partezettel der in den Jahren 1942-1946 verstorbenen Schwestern.

${ }^{24}$ GA-KTGL, sygn. BIIIb 6, Verschiedene Verzeichnisse, 1927-1990. 
statystykę całego Zgromadzenia od 1895 do 1919 roku $^{25}$. Dane z początkowego okresu Zgromadzenia od 1868 do 1895 roku, podano na początku tej księgi w zestawieniu zbiorczym. Później co roku podawano na dzień 1 stycznia wykaz wszystkich domów w kolejności ich powstania wraz z liczbą przebywających w nich służących, rekonwalescentek, sierot, wychowanek, dzieci szkolnych, uczennic szkół niedzielnych i szkół robót oraz dzieci przedszkolnych. Końcowe posumowanie liczebności poszczególnych grup pozwala uzyskać dokładne dane dla całego Zgromadzenia. Podobny schemat mają dwie kolejne księgi, obejmujące lata 1920-1935 i 1935-1938 ${ }^{26}$, z tą różnicą, że zawierają one osobną statystykę dla każdej prowincji Zgromadzenia. W zasobie archiwum generalnego znajdują się również schematyzmy, roczniki statystyczne (tzw. Berichty) lub okolicznościowe przeglądy statystyczne $\mathrm{z}$ działalności Zgromadzenia ${ }^{27}$. Prezentują one raport o stanie liczbowym domów, dzieł i sióstr. Wstępy do tych publikacji często zawierają opisy zmian, jakie zaszły w Zgromadzeniu i poszczególnych prowincjach w przeciągu roku. Znalazły się w nich echa takich wydarzeń, jak: zamykanie i otwieranie placówek, budowa nowych domów, obchody jubileuszów i świąt. Do sprawozdań tego typu dołączone są spisy z danymi personalnymi członków zarządów prowincji, przełożonych i asystentek, imienne listy sióstr z każdego domu oraz tych, które zostały w danym roku obłóczone, złożyły pierwszą lub wieczystą profesję. Do materiałów sprawozdawczych należą również sprawozdania z kapituł generalnych i zarządu Zgromadzenia ${ }^{28}$, które zawierają najczęściej tylko zarządzenia i uchwały. Brakuje w nich konkretnych faktów i bieżących informacji. Pewnym wyjątkiem jest tutaj sprawozdanie $\mathrm{z}$ dwunastu lat urzędowania przełożonej generalnej Ignacji Egger $^{29}$, w którym dokładnie przedstawiono stan materialny i personalny Zgromadzenia w latach 1906-1918. Z dużą dokładnością sporządzono również sprawozdanie do Stolicy Apostolskiej z lat 1904-1924.

\footnotetext{
${ }^{25}$ GA-KTGL, sygn. AIIId 2, Tätigkeit. Statistik, Berichterstattung, 1895-1919.

${ }^{26}$ GA-KTGL, sygn. AIIId 3, Tätigkeit. Statistik, Berichterstattung, 1920-1935; GAKTGL, sygn. AIIId 4, Tätigkeit. Statistik, Berichterstattung, 1935-1938.

${ }^{27}$ GA-KTGL, Jahres-Ausweise, sygn. AIIIb 1 - AIIIb 43.

28 GA-KTGL, sygn. AIIb 1-AIIb 11, Bestimmungen und Anordnungen der Generalkapitel und der Generaloberinnen, 1877-1977.

${ }^{29}$ GA-KTGL, sygn. AIIIb 21, Bericht über die Amtstätigkeit der Ehr. Generaloberin Schw. M. Ignatia Egger in den letzten 12 Jahren 1906-1918.
} 
Obejmuje ono właściwie wszystkie dziedziny życia całego Zgromadzenia: organizację, prawo własne, finanse, wykształcenie członkiń, działalność, duchowość, tradycje $\mathrm{e}^{30}$. Podsumowując, dokładna analiza wszystkich dostępnych w archiwum generalnym źródeł statystycznych i sprawozdawczych pozwala ustalić podstawowe dane odnoszące się do członkiń i działalności Zgromadzenia.

Ciekawą grupę źródeł, dotyczącą misji szkolno-wychowawczej Zgromadzenia, stanowią plany nauczania i wychowania oraz reguły dla wychowanek Instytutów Marii ${ }^{31}$. Niestety, chociaż działalność edukacyjna była głównym celem Zgromadzenia, dokumentacja szkolna jest niekompletna. W zasobie archiwum generalnego nie ma żadnych katalogów szkolnych, protokołów rad pedagogicznych, dokumentacji z przebiegu nauczania itp. Archiwalia tego typu są za to dostępne $\mathrm{w}$ archiwach prowincjalnych.

Rozwój Zgromadzenia można prześledzić na podstawie jego dość obszernej korespondencji $\mathrm{z}$ urzędami cywilnymi i kościelnymi ${ }^{32}$. Do dzisiaj zachowała się tylko korespondencja wychodząca, którą wpisywano do kopiariuszy. Są to przede wszystkim prośby o zatwierdzenie

${ }^{30}$ GA-KTGL, sygn. AIIIc 1, Berichterstattung an den Heiligen Stuhl laut Canon 510 des Cod. jur. can., 1924.

${ }^{31}$ GA-KTGL, sygn. DIh 1, Erziehungsplan für die Institute der Gesellschaft der Töchter der Göttlichen Liebe, 1883; GA-KTGL, sygn. DIh 2, Regeln für die Instituts=Zöglinge der Töchter der Göttlichen Liebe, 1884; GA-KTGL, sygn. DIh 3, Lehrplan für die Wiederholungsschule; GA-KTGL, sygn. DIh 4, Lehrplan der ,getheilten einclassigen Privat-Volkschule“ im Institute der Töchter der Göttlichen Liebe; GAKTGL, sygn. DIh 5, Lehrplan für die zweiclassige Privat-Mädchenschule des HerzMaria-Klosters in Weinhaus, Johannesgasse 13.

${ }^{32}$ GA-KTGL, sygn. AVa 1 - AVa 4, Korrespondenz der KTGL mit Bischöfen, Priestern und weltlichen Persönlichkeiten. Briefe, 1887-1922; GA-KTGL, sygn. AVb 3, Gesuche, Berichte an und für kirchliche und weltliche Behörden, 1880-1882; GAKTGL, sygn. AVb 4, Eingaben an Ordinariate wegen staatlicher AnerkennungsNiederlassungen, 1884-1897; GA-KTGL, sygn. AVb 5, Gesuche, Berichte an und für kirchliche und weltliche Behörden, an die Habsburgerfamilie und dgl., 1885-1916; GA-KTGL, sygn. AVb 6 - AVb 11, Gesuche, Berichte an und für kirchliche und weltliche Behörden, an die Habsburgerfamilie und dgl., 1887-1918; GA-KTGL, sygn. $\mathrm{AVb}$ 12, Gesuche, Berichte an und für kirchliche und weltliche Behörden, 1918-1930; GA-KTGL, sygn. AIVb 1, Empfehlungsschreiben zum Behufe der Apostolischen Approbation der Konstitutionen der Töchter der Göttlichen Liebe, 1884-1897; GAKTGL, sygn. AIVd 1, Dokumente betr. die Bestätigungen der Konstitutionen und der Kongregation der Töchter der Göttlichen Liebe, 1889-1898; GA-KTGL, sygn. AIVd 2-AIVd 4, Römische Angelegenheiten, 1887-1946. 
Zgromadzenia i Konstytucji, podania o uzyskanie pozwoleń na kwestowanie i otwieranie nowych dzieł oraz różne sprawozdania z działalności. W zasobie archiwum brakuje korespondencji przychodzącej, której nie odnotowywano w księgach. Z tej przyczyny źródła te są jednostronne i na ich podstawie nie można w pełni odtworzyć przebiegu załatwianych spraw. W spuściznach przełożonych generalnych jest z kolei sporo listów od sióstr, które ukazują ciekawy obraz życia Zgromadzenia. Za najbardziej interesujące uważam listy pochodzące od sióstr z Polskiej Prowincji ${ }^{33}$. Dotyczą one zarówno spraw osobistych, jak i różnych problemów wspólnotowych.

Dotykając tematu spuścizn członkiń Zgromadzenia, należy zaznaczyć, że ważną i najobszerniejszą część archiwaliów stanowi spuścizna założycielki Franciszki Lechner ${ }^{34}$. W jej skład wchodzi między innymi dokumentacja osobista, korespondencja, notatki oraz pamiątki i opracowania związane z osobą Założycielki. Cennym źródłem informacji dla badaczy historii Zgromadzenia są zwłaszcza jej listy okólne, zawierające wskazówki, polecenia i opisy ważnych wydarzeń ${ }^{35}$.

Na zakończenie krótkiej charakterystyki zasobu Generalnego Archiwum Zgromadzenia Córek Bożej Miłości w Wiedniu można stwierdzić, że zachowane akta, chociaż w pewnym stopniu zdekompletowane, stanowią wystarczająca bazę źródłową do opracowania dziejów Zgromadzenia w jego podstawowych liniach rozwoju.

\footnotetext{
${ }^{33}$ GA-KTGL, sygn. DIIIc 5, Briefe na Mutter Kostka Bauer von Schwestern aus der polnischen Provinz, 1939-1941.

${ }^{34}$ GA-KTGL: Mutter Franziska Lechner: sygn. DIa 1-DIa 24, Leben und Wirken; sygn. DIb 1-DIb 13, Bearbeitungen über Mutter Franziska Lechner und die KTGL; sygn. DIc 1, Korrespondenz betr. die Beatifikation der Mutter Franziska Lechner; sygn. DId 1-DId 7, Religiöse Gebrauchsgegenstände von Mutter Franziska Lechner; sygn. DIe 1-DIe 3, Tägliche Gebrauchsgegenstände von Mutter Franziska Lechner; sygn. DIf 1, Sterbliche Überreste von Mutter Franziska Lechner; sygn. DIg 1-DIg 12, Gebetsbücher, Regeln, Konstitutionen und dgl. schriftlicher Nachlaß; sygn. DIh 1-DIh 6, Regeln für die Zöglinge und verschiedene Lehrpläne; sygn. DIi 1-DIi 5, Verschiedene Andenken von Mutter Franziska Lechner; sygn. DIj 1, Sonstiges.

${ }^{35}$ GA-KTGL, sygn. DIa 13, Mutter Franziska Lechner. Zirkulare, 1876-1893.
} 


\section{Bibliografia}

\section{Źródła archiwalne}

\section{Generalne Archiwum Zgromadzenia Córek Bożej Miłości w Wiedniu (GA-KTGL)}

Akta ustawodawcze, Statuty, sygn.: AIa 1 - AIa 9; Konstytucje i Reguły, sygn.: AIb 1, AIb 3, AIb 4, AIb 6 - AIb 12, AIb 14, AIb 15, AIb 17 AIb 21; Aprobata Zgromadzenia i Konstytucji, sygn.: AIc 1 - AIc 4.

Ewidencja, Księgi ewidencyjne sióstr, sygn.: BIa 1, BIa 2; Księgi ewidencyjne obłóczyn, sygn.: BIb 1 - BIb 3, BIb 8; Księgi ewidencyjne profesji wieczystej, sygn.: BIc 1, BIc 2.

Korespondencja ZCBM z władzami kościelnymi i cywilnymi, Korespondencja ZCBM z osobistościami duchownymi i świeckimi, sygn.: AVa 1 - AVa 4; Korespondencja ZCBM z władzami kościelnymi i cywilnymi, z Habsburgami, z różnymi osobistościami świeckimi, sygn.: AVb 3 - AVb 12.

Kroniki, księgi pamiątkowe, Kroniki całego Zgromadzenia, sygn.: EIIa 1 EIIa 10.

Matka Franciszka Lechner, Życie i działalność, sygn.: DIa 1 - DIa 24; Opracowania o M. Franciszce Lechner i ZCBM, sygn.: DIb 1 - DIb 13; Korespondencja dotycząca beatyfikacji M. Franciszki Lechner, sygn. DIc 1; Pamiątki religijne - jej osobiste i z nią związane, sygn.: DId 1 DId 7; Przedmioty codziennego użytku M. Franciszki Lechner, sygn.: DIe 1 - DIe 3; Śmiertelne szczątki M. Franciszki Lechner, sygn. DIf 1; Modlitewniki, Reguły, Konstytucje itp. piśmienna spuścizna, sygn.: DIg 1 - DIg 12; Reguły dla wychowanek, różne plany nauki w szkołach, sygn.: DIh 1 - DIh 6; Różne pamiątki po M. Franciszce Lechner, sygn.: DIi 1 - DIi 5; Pozostałe, sygn. DIj 1.

Matka Kostka Bauer - przełożona generalna ZCBM, Listy M. Kostki Bauer do sióstr i listy od sióstr, sygn. DIIIc 5.

Siostry zmarłe, Akta personalne zmarłych sióstr, sygn.: BIIIa 1 - BIIIa 20;

Wspomnienia pośmiertne, nekrologi, obrazki oraz różne spisy zmarłych sióstr, sygn.: BIIIb 1 - BIIIb 4, BIIIb 6.

Sprawozdawczość, Działalność ZCBM - statystyka wewnętrzna, sygn.:

AIIId 2 - AIIId 4; Sprawozdania z działalność ZCBM, sygn.: AIIIb 1 AIIIb 43; Sprawozdania i przeglądy statystyczne, schematyzmy, sygn. AIIIc 1.

Władze kościelne. Dokumenty i korespondencja, Stolica Apostolska, sygn.

AIVb 1; Sprawy rzymskie, sygn.: AIVd 1 - AIVd 4.

Włączenie do ZCBM, Obłóczyny, profesja, sygn. BIIc 5.

Zarządzanie Zgromadzeniem, Uchwały i zarządzenia kapituł generalnych i przełożonych generalnych, sygn.: AIIb 1 - AIIb 11. 


\section{Archiwum Polskiej Prowincji Zgromadzenia Córek Bożej Miłości w Krakowie (APP-ZCBM)}

Byrdy A., Rzut oka na działalność Zgromadzenia Córek Bożej Miłości w Polsce w okresie 75-lecia 1886-1961, Kraków 1961, mps, b. sygn.

Rusztyn Z., Działalność oświatowo-wychowawcza Zgromadzenia Córek Bożej Mitości na ziemiach polskich 1885-1980, Kraków 1980, mps, b. sygn.

Stanochowa M., Tajne nauczanie w Krakowie 1939-1945, Kraków 1973, mps, b. sygn.

\section{Opracowania}

Rusztyn Z., Inwentarz generalnego zasobu archiwalnego Zgromadzenia Córek Bożej Miłości w Wiedniu (1848-1991), ABMK, t. LXVI, Lublin 1996.

Rusztyn Z., Zgromadzenie Córek Bożej Miłości w latach 1868-1919. Struktura i rozwój terytorialny, Lublin 2004.

Rusztyn Zofia FDC, Zgromadzenie Córek Bożej Miłości w latach 1939-1947,

[w:] Żenskie Zgromadzenia Zakonne w Polsce 1939-1947, t. 12, Lublin 1999. Krzyżan J., Pedagogia Zgromadzenia Córek Bożej Miłości, [w:] Pedagogie katolickich zgromadzeń zakonnych. Historia i wspótczesność, t. 3, red. Kostkiewicz Janina, Kraków 2015.

JUSTYNA KRZYŻAN FDC

\section{ŹRÓDŁA DO DZIEJÓW ZGROMADZENIA CÓREK BOŻEJ MIŁOŚCI W GENERALNYM ARCHIWUM ZGROMADZENIA CÓREK BOŻEJ MILOŚCI W WIEDNIU}

Streszczenie: W artykule przedstawiono źródła do dziejów Zgromadzenia Córek Bożej Miłości, znajdujące się w Generalnym Archiwum Zgromadzenia Córek Bożej Miłości w Wiedniu. Celem łatwiejszego zrozumienia poruszanych treści, we wstępie ukazano w krótkim zarysie charakter, organizację i działalność tej wspólnoty zakonnej. Powstałe w drugiej połowie XIX wieku Zgromadzenie stawiało sobie za cel pomoc dziewczętom migrującym ze wsi do miast w poszukiwaniu pracy oraz kształcenie dzieci i młodzieży w różnych typach szkół. Podejmowana przez siostry Córki Bożej Miłości działalność w zasadniczy sposób wpłynęła na charakter wytworzonej dokumentacji archiwalnej. Na rodzaj i rozmiar spuścizny aktowej generalnego zasobu archiwalnego wpływ miała również struktura Zgromadzenia. Do 1919 roku, czyli do momentu wyodrębnienia pierwszych czterech prowincji, zarządzane ono było centralnie przez przełożoną generalną i jej radę rezydującą w Domu Macierzystym w Wiedniu. W konsekwencji podziału na prowincje, większość dokumentacji pozostawała w kancelariach i archiwach prowincjalnych. Do archiwum generalnego trafiały jedynie akta bardziej selektywne. Zasób archiwum generalnego obejmuje dzisiaj zarówno akta całego Zgromadzenia, jak i akta poszczególnych prowincji. W artykule podano 
ogólny wykaz akt całego Zgromadzenia i dokonano krótkiej charakterystyki niektórych jednostek archiwalnych, wchodzących w skład poszczególnych grup i podgrup rzeczowych. Omówiono m.in. specyfikę takich archiwaliów, jak: kroniki generalne, Statuty, Reguły, Konstytucje oraz dokumentację związaną z ich opracowywaniem i zatwierdzaniem. Analizie poddano materiał dotyczący członkiń Zgromadzenia: księgi ewidencyjne sióstr i kandydatek, protokoły z posiedzeń Rady Prowincjalnej, spisy przełożonych i asystentek, akta personalne zmarłych sióstr, wspomnienia pośmiertne i nekrologi. Szczególną uwagę zwrócono na materiały statystyczne i sprawozdawcze, które mogą posłużyć do opracowania tematyki związanej z działalnością Zgromadzenia, ponieważ ukazują m.in. liczebność poszczególnych grup osób, do których skierowana była działalność sióstr Córek Bożej Miłości. Rozwój Zgromadzenia można prześledzić również na podstawie jego korespondencji z urzędami kościelnymi i cywilnymi oraz źródeł dotyczących jego misji szkolno-wychowawczej, a także spuścizn członkiń. Zachowane akta stanowią wystarczającą bazę źródłową do opracowania dziejów Zgromadzenia.

Słowa kluczowe: Zgromadzenie Córek Bożej Miłości, Generalne Archiwum Zgromadzenia Córek Bożej Miłości, Wiedeń.

\title{
SOURCES FOR THE HISTORY OF THE CONGREGATION OF DAUGHTERS OF DIVINE LOVE IN THE GENERAL ARCHIVES OF THE CONGREGATION IN VIENNA
}

\begin{abstract}
The article presents the sources for the history of the Congregation of Daughters of Divine Love, located in the General Archives of the Congregation of Daughters of Divine Love in Vienna. In order to facilitate the understanding of the content, the introduction briefly outlines the nature, organization and activities of this religious community. Established in the second half of the 19th century, the Congregation aimed to help girls migrating from the countryside to cities in search of work and to educate children and youth in various types of schools. The activities undertaken by Daughters of Divine Love fundamentally influenced the nature of the archival documentation produced. The structure of the Congregation also influenced the type and size of the archival resources. Until 1919, that is until the establishment of the first four provinces, the Congregation was managed centrally by the superior general and her council residing at the Mother House in Vienna. As a result of division into provinces, most of the documentation remained in the provincial offices and archives. Only more selective files went to the general archive. The resources of the general archive now include both the files of the whole congregation and the files of individual provinces. The article gives a general list of files of the whole congregation and a brief description of some of the archival units included in particular groups and subgroups. Among others, the article specifies such archival materials as: general chronicles, Statutes, Rules, Constitutions and documentation related to their development and approval. It also analyses the material concerning the members of the Congregation: records of sisters and candidates, minutes from the meetings of the Provincial Council, lists of superiors and assistants, personal files of the dead sisters, posthumous memories and obituaries.
\end{abstract}


Particular attention has been paid to statistical and reporting materials that can be used to develop topics related to the activities of the Congregation, as they show the number of particular groups to whom the Daughters of Divine Love directed their activities. The development of the Congregation can also be traced on the basis of its correspondence with church and civil offices as well as sources concerning its educational mission and the legacy of the Sisters. The preserved files constitute a sufficient source base for the development of the history of the Congregation.

Keywords: Congregation of Daughters of Divine Love, General Archives of Congregation of Daughters of Divine Love, Vienna.

Translated by Hanna Rybkowska 